\title{
NUDA I NUDZIARZE. DOŚWIADCZENIE „NUDNEGO” WE WSPÓtCZESNOŚCI
}

Małgorzata Kubacka

Uniwersytet im. Adama Mickiewicza w Poznaniu

\section{/// Wstęp}

Nuda stanowi marginalny obszar zainteresowań badawczych socjologów. Mimo to na przestrzeni ostatnich dwudziestu lat można zauważyć wzrost liczby publikacji poświęconych temu zjawisku. Większa część z nich powstała jednak na gruncie innych niż socjologia dziedzin nauki. W literaturze wiele uwagi poświęca się zagadnieniu wszechobecności nudy, ale ogólna liczba analiz mogłaby wskazywać na coś przeciwnego. Nuda jako przedmiot badań socjologicznych wciąż pozostaje niedoceniona. W poniższym artykule skupiam się na (często pomijanym, banalizowanym, a nawet infantylizowanym) problemie nudy.

Nie podejmuję tego tematu z opisanej już dość dokładnie perspektywy historycznej czy literackiej (Goodstein 2005, Kuhn 1976). Koncentruję się na dyskursywnych reprezentacjach nudy oraz „człowieka nudnego” przedstawionych na wybranych portalach internetowych. Proponuję typologię współczesnych nudziarzy: ich cechy, charakterystyczne zachowania i wartości im przypisywane. Opisuję krótko elitaryzację i demokratyzację nudy, by wskazać, jakie szersze procesy wpłynęły na jej obecny kształt. Na końcu wskazuję, że nuda jest zjawiskiem ambiwalentnym, sytuacyjnym oraz relacyjnym.

\section{/// Elitaryzacja i demokratyzacja nudy}

Dotychczasowe próby zdefiniowania nudy są zgodne w jednym aspekcie: nuda to pojęcie wieloznaczne. Uznaje się ją za zjawisko typowe dla 
nowoczesności (Dalle Pezze, Salzani 2009: 5-15, Svendsen 2005: 11). Analizuje się ją najczęściej poprzez odwołania do pokrewnych terminów, z którymi pozostaje w silniejszym lub słabszym związku (zob. Dalle Pezze, Salzani 2009: 17). Wskazuje się na filiację nowoczesnej nudy (modern boredom) z terminami poprzedzającymi jej pojawienie się i określającymi podobny zespół charakterystyk. Wymienia się w tym przypadku m.in. acedię, taedium vitae, melancholię, ennui, spleen. Jednocześnie jednak podkreśla się konieczność odróżnienia współczesnej nudy od wymienionych wyżej pojęć, co odbywa się przy założeniu, że trudno dokonać pełnego, wyczerpującego opisu tego zjawiska (zob. Goodstein 2005).

Do końca XVIII wieku nudę dzielono na dwa rodzaje (Goodstein 2005, Svendsen 2005). Uprzywilejowane warstwy społeczne miały doświadczać nudy egzystencjalnej - „choroby filozoficznej”, melancholii, acedii, depresji, pustki, izolacji, wstrętu (Toohey 2012: 13). Pozostali skazani byli na mniej wysublimowaną i mniej ceniona „zwykłą nudę”. Odczuwanie nudy długo różnicowano ze względu na takie zmienne, jak status społeczny, prestiż czy wykształcenie. Do najczęściej wymienianych kategorii osób znających zjawisko $z$ autopsji należeli mnisi, których dopadał tzw. daemon meridianus (demon południa), czyli grzech acedii (zob. Goodstein 2005: 3540, Svendsen 2005: 49-52, Zdrenka 2012: 125-130). Ennui oraz melancholia łączone były ze sztuką, kreatywnością, a nawet rodzajem wewnętrznej wrażliwości pozwalającej doświadczać świata w wyjątkowy, wysublimowany, intelektualny sposób (por. Goodstein 2005: 54-64). Tak pojęta nuda dotyczyła przede wszystkim osób zajmujących się pracą twórczą i przedstawicieli klas wyższych. Nudzili się arystokraci, poeci, filozofowie, artyści, intelektualiści urodzeni pod znakiem Saturna (melancholia generosa). Nudę wynikająca z nadmiaru wolnego czasu, monotonnej pracy, oczekiwania na swoją kolej uznawano za bezwartościową. Psychologiczna (i uleczalna) niemoc znalezienia „prawdziwego celu” mieszkańców przedmieść także nie miała w sobie nic filozoficznego, nic egzystencjalnego, nic wartego realnego zainteresowania (por. Kuhn 1976: 6).

Klasyfikacje nudy były naznaczone, jak zauważa Goodstein (tamże: 55), „elitarystycznymi uprzedzeniami”. Chodziło w nich o dość sztuczne wydzielenie opisu nudy zgodnej z ówczesnym kanonem literackim. Toohey wskazuje, że możliwa przyczyną pomniejszania znaczenia i unikania zainteresowania „zwykłą” nudą było utożsamienie jej z fazą dzieciństwa. Nudę „,egzystencjalną” zdaniem tego autora należy uznać za „,...] przypadłość, o której raczej się czyta i dyskutuje, niż rzeczywiście jej doświadcza” (Toohey 2012: 13). Konsekwencją takiego podziału jest marginalizowanie 
roli podstawy historycznej i kulturowej wspólnej każdemu typowi nudy. Współczesna nuda została zdemokratyzowana ${ }^{1}$ (Goodstein 2005: 108120). Przyczyniło się do tego rozczarowanie romantyczną koncepcją świata, rozwoju jednostkowego, kryzys tradycji i znaczenia oraz upowszechnienie dostępności wolnego czasu (zob. Brissett, Snow 1993: 244). Goodstein nowoczesne „doświadczenie bez właściwości” łączy z „demokratyzacja sceptycyzmu”2 (Goodstein 2005: 10, 108-120) oraz stworzeniem „nowej retoryki refleksji nad subiektywnym doświadczeniem". Zjawiska te maja swoje przyczyny w szybkich zmianach zachodzących w XIX i XX wieku. Najważniejsze z nich to nowa wizja czasu i nowoczesnego podmiotu oraz urbanizacja, industrializacja i modernizacja. Opisane w tym wstępie procesy oraz zmiany podejść do nudy stanowią tło dla współczesnego postrzegania zarówno samej nudy, jak i tego, co jest nudne.

Obecnie prawo do odczuwania nudy nie jest uzależnione od zajmowanej pozycji społecznej. Nuda jest „przywilejem” współczesnego człowieka, dodajmy - każdego człowieka. Co więcej, jak zauważa Svendsen (2005: 21-22), na przestrzeni kilku ostatnich stuleci nuda powiększyła swój zakres oddziaływań: jej „ilość” wzrosła, a świat stał się nudniejszy. Spacks (1995) łączy ten proces z dużym naciskiem, jaki kładzie się na posiadanie praw jednostkowych (zwłaszcza prawa do szczęścia), oraz przywiązywaniem wagi do emocji towarzyszących codziennemu doświadczeniu. Rozprzestrzenianie się nudy ma swoje przyczyny także w popularnym koncepcie rozwoju własnej refleksyjności, świadomości, życia wewnętrznego oraz wynikającej z niego konieczności „budowania” swoich codziennych doświadczeń w sposób celowy i zorientowany na jakość. Procesy opisane powyżej wpłynęły na zmianę sposobu rozumienia zarówno samej nudy,

\footnotetext{
${ }^{1}$ Demokratyzacja zjawiska nudy nie oznacza oczywiście, że nuda jest wyrażana czy „praktykowana” tak samo przez każdego człowieka lub też że wszyscy ludzie pracują nad nudą w taki sam sposób. Nie oznacza też, że wcześniej nie istniała nuda „sytuacyjna”. Powołując się na koncept demokratyzacji nudy, pragnę podkreślić, że opisana klasyfikacja nudy odzwierciedla epokowe mody i kanony. Kanony, które nie do końca odpowiadają współczesności, a może nawet temu, czego jednostki realnie doświadczaja (Toohey 2012: 13). Współczesne relacje odnoszące się do nudy w dużej mierze straciły swój romantyczny, literacki, „egzystencjalny” charakter. To jednak nie wyklucza istnienia zróżnicowanych społecznie strategii zarządzania nudą. W tym artykule nie analizuję szczegółowo wspomnianych strategii. Demokratyzacja nudy, rozumiana jak wyżej, zmusza jednostki do podejmowania nowych sposobów działań i podejść wobec nudy. W analizowanym materiale zmiana ta uwidacznia się wtedy, gdy opisuję wyłanianie się nowego dyskursu nudy tworzonego przy udziale „nudziarzy z wyboru”. Typ ten kontestuje utarte znaczenia „interesującego” oraz „demokratycznie negatywne” znaczenia „nudnego”. Tym samym poszerza obszar niepewności i otwiera drogę do powstawania nowych relacji społecznych w polu „nudnego" i ,interesującego". Jednocześnie ustalane są nowe reguły mogące wskazywać na różnicę kompetencji oraz różnice klasowo-warstwowe pomiędzy poszczególnymi typami nudziarzy.

${ }^{2}$ Wszystkie cytaty z języka angielskiego w tłumaczeniu autora.
} 
jak i tego, co jest nudne. W tym kontekście szczególnie interesujące wydaja się dyskursywne strategie tworzenia konceptu współczesnego „człowieka nudnego" oraz ich konsekwencje dla postrzegania samej nudy.

\section{/// Metoda}

Przeprowadzono jakościową analizę tekstów $w^{3}$ dobranych w toku procedury cyklicznej ${ }^{4}$. Obejmują one artykuły internetowe i komentarze do nich oraz wypowiedzi z forów internetowych publikowane od początku XXI wieku5 , w których pojawiają się określenia „,nudny”, „nudziarz” lub „nuda” oraz watti dyskusyjne na forach internetowych poruszające problem „bycia nudnym" albo metod jego przezwyciężania. Na wspomnianych forach poruszano różnorodne wątki (nie udało się znaleźć forum internetowego/bloga/serwisu w całości poświęconego nudzie). Tylko jedno z forów poświęcone było konkretnej tematyce chorób psychicznych. Rozmowy o nudzie i powstające teksty ulokowane są w różnorodnych miejscach. Poruszanie problemu nudy w Internecie ma zazwyczaj charakter incydentalny. Nuda jest najczęściej wątkiem pobocznym. Nie można mówić o całych wspólnotach internetowych dyskutujących o nudzie w jednym miejscu, jeśli uwzględnia się (jak w tym przypadku) wyłącznie polskojęzyczne strony. Taki dobór materiałów posłużył do odtworzenia potocznych sposobów konceptualizacji i wartościowania wizerunku osoby nudnej, a także do wskazania codziennych sposobów doświadczania nudy.

W przedstawionym badaniu dyskurs rozumiany jest jako całość praktyk, reguł oraz znaczeń wykraczająca poza rozróżnienia zjawisk językowych i pozajęzykowych. Jest to działanie podejmowane w komunikacji pisemnej przez twórców tekstów oraz pomiędzy nimi (por. Wodak, Krzyżanowski 2011: 16). Wymiar dyskursywny (językowy, lingwistyczny) prze-

\footnotetext{
${ }^{3}$ Pod uwagę brano te teksty, w których występuje przynajmniej jedno ze słów takich jak: „nuda”, „nudny”, „,nudna”, ,znudzenie”, „,nudziarz”. Istotna była przede wszystkim wysoka pozycja w wyszukiwarkach Google, Bing, Yahoo, MSN lub Altavista (pierwsze strony wyników wyszukiwania). Warunkiem włączenia tekstu do próby było również miejsce jego publikacji: polskie portale, wortale, blogi, fora internetowe.

${ }^{4} \mathrm{Na}$ początku zebrano niewielką liczbę tekstów i przeanalizowano ich zawartość. Następnie włączano kolejne teksty aż do momentu, w którym korpus osiągnął nasycenie (kolejne próby nie dostarczały nowych reprezentacji) (zob. Wodak, Krzyżanowski 2011).

${ }^{5}$ Zastosowana metoda wyszukiwania tekstów dostarczyła materiałów, z których najstarszy uwzględniony tekst datowany był na 2001 rok, a najmłodszy na 2015 rok. Nie włączono do próby wszystkich powstałych w tym czasie materiałów o nudzie, a jedynie te, które pojawiały się w wyszukiwarkach jako pierwsze, aż do momentu, w którym osiagnnięto punkt nasycenia danych. W sumie analizą objęto 40 adresów internetowych (jeśli tekst składał się z kilku stron, analizowano również podstrony, jednak nie liczono ich jako odrębnych adresów).
} 
plata się z niedyskursywnym (pozajęzykowym). Dyskurs jest zbiorem reguł oraz praktyk służących do wytwarzania znaczeń, dlatego też wyznacza zakres możliwości tworzenia konkretnych procesów lub zjawisk (Laclau 2002: 560, Jørgensen, Phillips 2002: 24-59).

Kluczowym elementem w badanym dyskursie są pojęcia „nudy” i „nudnego”. Dyskurs, zgodnie z przyjętym tu założeniem, kreuje znaczenia, sensy i tożsamości, posługując się strategią odróżniania lub upodabniania. Każdy przedmiot/podmiot w dyskursie jest tworzony poprzez porównanie $z$ antagonistycznym (logika różnicy) lub podobnym przedmiotem/ podmiotem (logika równoważności). Znaczenia nieustannie poddawane są nowym interpretacjom, porównywane z innymi i negocjowane. Analiza umożliwia wgląd w szerszy kontekst społecznie tworzonych znaczeń związanych z nuda. Pozwala na zmapowanie procesów tworzenia znaczeń oraz ukazanie, jak zostaja skonwencjonalizowane i uznane za naturalne. Ernesto Laclau i Chantal Mouffe (Jørgensen, Phillips 2002: 33) uznali, że taka sama logika może być zastosowana do całego pola działań społecznych. Jednostki zachowuja się tak, jakby rzeczywistość społeczna była obiektywna, pewna i niezmienna. Jednocześnie autorzy podkreślaja, że ani język, ani tożsamość czy społeczeństwo nie będą nigdy jednoznaczne. Charakteryzuje je raczej elastyczność i zmienność niż stałość. Dlatego też ta teoria doskonale obrazuje kluczowe cechy współczesnego świata. Celem analizy dyskursu nie jest odkrywanie obiektywnych praw, lecz wskazywanie na dyskursywne kreowanie znaczeń odnoszących się do rzeczywistości społecznej, a w efekcie wytwarzanie jej jako „naturalnej” i „obiektywnej”. W niniejszym artykule opisuje, jakie cechy, zachowania oraz wartości przypisywane są nudziarzom oraz wskazuję na konsekwencje takiego sposobu reprezentowania człowieka nudnego dla doświadczania nudy.

\section{/// Typy nudziarzy}

Poniższy opis typów nudziarzy uwzględnia styl językowy, którym posługiwali się twórcy analizowanych tekstów, ale sam w sobie stanowi rekonstrukcję wytwarzanej oddolnie wiedzy, ponieważ autorzy prezentowali osoby nudne w ogólny sposób, skupiając uwagę na pojedynczych cechach albo charakterystycznych dla nich zachowaniach. 


\section{Osoba „bez właściwości”}

Za nudziarza uznaje się osoby „bez właściwości”. Nie wykazują one głębszego zainteresowania światem zewnętrznym, popkulturą, a niekiedy nawet sobą samym. „Nudna osoba [...] to taka, która nie ma swoich zainteresowań [...]" (mata hari 2015). Trudno jest takiej osobie sprawić przyjemność, ponieważ na wszelkie bodźce reaguje w podobny, pozbawiony emocji sposób. Jej codzienne życie stanowi rodzaj zagadki dla otoczenia: potrafi spędzać całe dnie na podejmowaniu aktywności, które nie maja głębszego znaczenia. Działanie nudziarza charakteryzują pozbawione sensu schematyczność i rytualizm. Brakuje mu spontaniczności, nie jest też kreatywny. W konsekwencji jego życie naznaczone jest przewidywalnościa oraz monotonia.

[...] [N]udny może być człowiek przewidywalny, schematyczny, dla którego każdy dzień jest niemal identycznym rytuałem, który właśnie nie pozwala sobie na odrobinę spontaniczności, idiotycznych pomysłów, kreatywności w działaniu. Wtedy jego życie jest ułożone, monotonne, więc może być odbierane za nudne (Sasza 2017).

Spotkanie osoby „bez właściwości” to wyjątkowo nieprzyjemne, męczące doświadczenie, ponieważ przypisuje się jej zdolność do zarażania swoim marazmem wszystkich, z którymi wchodzi w interakcję. Nawiązanie rozmowy jest niemal niemożliwe: nudziarz ten potrafi odpowiadać na pytania tylko poprzez krótkie, monosylabiczne wypowiedzi lub poprzez powtarzanie obiegowych opinii. Bardzo rzadko mówi on o sobie samym, niemal nigdy nie ujawnia własnego zdania na dany temat, za to $z$ upodobaniem stosuje wielkie kwantyfikatory („ludzie”, „świat”, „oni”) czy uogólniające stwierdzenia (,tak już jest”, „no i tak”, „zdarza się”, ,jest jak jest”, „bywa”, „no zobacz”). Nudziarz postrzegany jest również jako osoba, która posiada niskie kompetencje komunikacyjne: nie potrafi prowadzić rozmowy z innymi.

Dla mnie nudna osoba to taka, która [...] nie potrafi się elokwentnie wypowiedzieć i generalnie nie ma nic do powiedzenia. Trudno zresztą mieć coś do powiedzenia, kiedy się człowiek niczym nie interesuje i niczego nie czyta (Anemonne 2015). 
Nie potrafi także znaleźć tematu do rozmowy, po prostu nie wie, o czym konwersować, rzadko też słucha innych i wcale się z tym nie kryje. Nic go nie interesuje, nic nie porusza, jest apatyczny, depresyjny, wycofany, introwertyczny. Jego życie naznaczone jest monotonią, brakiem zmian, nudą. W konsekwencji nudziarz nie może pochwalić się bogatym życiem towarzyskim. Nie jest popularny, postrzega się go jako osobę nudną, nieprzystępna, z którą trudno spędza się czas.

Dopiero niedawno doszłam do wniosku, że nie reprezentuję sobą nic ciekawego co może intrygować i przyciagać ludzi. Nie prowadzę z nikim ciekawych rozmów, które nie mają końca, nie mam w sobie energii, chęci do życia. Jestem taką szarą myszką, która wysiaduje w domu i niczym się nie wyróżnia. W sumie to na tle innych koleżanek mam nijaki charakter. [...] W oczach znajomych jestem nudna bo z nią [koleżanka] wszyscy się śmieją i nie nikną rozmowy a ze mną tak. I w końcu w oczach chłopaków bo wydaje się nudną, nieprzystępną dziewczyną (Gość 2014).

Ma problemy z podejmowaniem najprostszych decyzji, woli oddawać inicjatywę innym i pozwala sobą kierować: brakuje mu asertywności. Rzadko wychodzi z domu, z reguly nie posiada przyjaciól, znajomych. Etykietę nudziarza nadaje się osobom, które nie cieszą się popularnością w kręgu towarzyskim. Nie jest w tym przypadku istotna jakość relacji, istotna jest ich ilość.

[...] Przez te 3 lata nie zaskoczył mnie niczym, nigdzie niespodziewanie nie zabrał - a w tym mieście nie brakuje fajnych miejsc, chodziliśmy tylko do kina, na pizzę i do parku. [...] Przez tyle lat on nie zrobił nic spontanicznego, wszystko zawsze dokładnie zaplanowane i to jeszcze głównie przeze mnie bo ostatnio o wszystkim każe decydować mnie. Na chwilę obecną strasznie się z nim nudzę i czasem nawet nie mam o czym z nim gadać (szafiarenka 2015).

Masz kolegów, koleżanki ? jak nie masz to chyba raczej jesteś nudziarzem... [...] (RuMcajs.! 2015).

Wobec wszelkich komentarzy pozostaje obojętny, niewzruszony. Określa się tę osobę mianem „cienia”, „ducha” lub mówi się o niej, że jest „nijaka”. 


\section{Freak}

Drugi typ nudziarza nazwany został $\mathrm{w}$ analizowanym materiale jako freak: dziwak, maniak, pasjonat. Wydawałoby się, że posiadanie pasji stanowi dokładne przeciwieństwo nudy. Podstawą wyróżnienia tego rodzaju staje się jednak nie tylko posiadanie hobby, zainteresowań, lecz fiksacja na punkcie jednego z nich oraz mania dotycząca obszaru nieznanego albo niezrozumiałego dla innych.

Nudny chyba najczęściej znaczy bez zainteresowań, ale również z zainteresowaniami, które nas zupełnie nie kręca. Nie interesuję się np. motoryzacją, za to znajomy się tym pasjonuje. Ciekawie jest kilka razy posłuchać co ma do powiedzenia na ten temat, jednak ciągłe gadanie tylko o tym byłoby właśnie nudne [...] (dziku_SKA 2015).

[...] Również nudnym jest człowiek, który przedstawiając swoje (nawet szerokie) zainteresowania posługuje się hermetycznym, specjalistycznym językiem, językiem, którego nie rozumiem (Wielokropek 2015).

Uznaje się, że osoba taka ma tylko jeden temat do rozmów, jedną rzecz, bez której stałaby się zupełnie nierozpoznawalna. Nudziarz bez właściwości nie potrafi komunikować się z innymi, zaś freak nie chce tego robić, ponieważ nie jest zainteresowany propozycjami innych. O takim nudziarzu można powiedzieć, że posiada dominującą właściwość, która przesłania wszelkie inne jego cechy. Freak bywa także egocentrykiem.

Dla mnie osobą nudna jest człowiek skoncentrowany na sobie, swoich przeżyciach, swoich pasjach, swoich..., swojej..., czyli osoba nie widząca świata poza czubkiem własnego nosa. (Wielokropek 2015).

Życie freaka zorganizowane jest wokół tej jednej aktywności. Potrafi on/ona zanudzać wszystkich ciąłym powtarzaniem opowieści o swojej pracy, hobby, zwierzęciu albo innym ważnym dla niego/niej aspekcie rzeczywistości, który nie jest równie ważny dla innych osób. 
Jakich ludzi uważam za nudnych? Z pewnością nie takich, którzy mało mówią. Mnie nudzą właśnie takie, które potrafią się rozwodzić monotonnym tonem o sprawach nieważnych, nieistotnych lub takich, które mnie totalnie nie obchodzą. Tam, gdzie pracuję jest taka pani: potrafi gadać o geniuszu swoich dzieci i o tym co ugotowała czy upiekła a ja nie znam tych dzieci a na gotowaniu znam się jak kura na gwiazdach (Mijanou 2015).

Każda próba zmiany tematu kończy się niepowodzeniem, ponieważ nudziarz tego rodzaju usilnie powraca do tego, co go najbardziej interesuje. Do tego typu zaliczyć można również osoby, które uwielbiają dużo mówić, wdają się w nieistotne szczegóły, rozwlekają swoje opowieści i jednocześnie nie słuchają innych. Gadulstwo, ciągłe opowiadanie o sobie, swoich osiągnięciach także włącza się w ten typ. Nudziarze-dziwacy są nastawieni na przekazywanie informacji w większym stopniu niż na ich odbieranie.

Z własnych obserwacji wydaje mi się, że osoby nudne są zazwyczaj:

- monotematyczne

- nie potrafia płynnie przeskakiwać na inne tematy rozmów (czasem wynika to z ich ogólnie małej wiedzy i powolnego kojarzenia faktów)

- skupiaja się bardziej na sobie (czy jest to opowiadanie o swoich sukcesach czy też zagłębianie się we własne problemy), z tego egocentryzmu wynika też ich...

- nieumiejętność słuchania i odbierania sygnałów zwrotnych od współrozmówcy (nie wiedzą kiedy przerwać wątek i przestać „,zanudzać”)

- ich komunikaty są zabarwione pesymistycznie, często „marudzą”, i wygłaszają postawę roszczeniową wobec świata (Izabela B. 2015).

Ich wizja świata jawi się innym jako płytka, ograniczona i w konsekwencji nudna.

\section{Chodzący ideał}

Nudna osoba to też taka, która staje się modelowym odzwierciedleniem społecznie pożądanych cech. Chodzący ideał jest zawsze miły i uprzejmy wobec każdego. Dba o to, by nikogo nie urazić, stara się unikać wszelkich 
konfliktów, a nawet najmniejszej różnicy zdań. Jest nadmiernie ugrzeczniony, zmanierowany i poprawny politycznie.

Jak dla mnie sprawiasz wrażenie człowieka przede wszystkim nudnego. Nie jesteś spontaniczny, ubierasz się „elegancko”, czyli bez polotu, interesujesz się rzeczami, którymi mało kto się interesuje, więc nie można z Tobą przeprowadzić niezobowiązującej konwersacji [...]. Facet nie może być porządny, poukładany, idealnie zorganizowany, bo jest wtedy strasznie przewidywalny, a to najgorsza rzecz, jaka może mi się przytrafić. Co to za życie, kiedy nie ma się żadnego urozmaicenia, wszystko jest według ustalonego schematu? [...] Muszą być jakieś emocje, wymiana zdań, musi się coś dziać. Inaczej bym zwariowała (kaisa_malene 2015).

Taki nudziarz adaptuje się do środowiska, dostosowuje swoje zachowanie i opinie do osób, wokół których się znajduje, przy czym robi to w sposób zauważalnie sztuczny. Cechować może go także rodzaj fałszywej skromności: celowo pomniejsza swoje znaczenie, sukcesy czy obniża własną wartość. Stara się działać tak, by wszyscy byli zadowoleni. Rzadko posługuje się negatywnymi sformułowaniami, nie przeklina, brzydzi się wszelkimi używkami i tym, co wniosłoby do jego życia element ryzyka albo zachwiałoby reputację. Jest zawsze poprawny, dobrze ubrany, prowadzi przykładne życie, nigdy się nie spóźnia. Chodzący ideał jest jednocześnie konformistą i megalomanem.

Grzeczne dziewczynki są nudne i prowadzą bardzo nudny żywot. Można im tylko współczuć. Grzeczne dziewczynki ubierają się jak w telewizji pokazują, że powinno się. Zachowują się jak gwiazdy i myślą, że są cool. One nie wiedzą co to znaczy ta prawdziwa radość kiedy tańczysz na łące na bosaka do ogniska w czerwonej sukience, bo z wesela uciekłaś (jasnoniebieska 2015).

W efekcie staje się kimś do bólu przewidywalnym, kto z codziennej rutyny i społecznych oczekiwań uczynił sens swojego życia. Można powiedzieć, że chodzący ideał osiągnął mistrzostwo w prowadzeniu small talków: zawsze i z każdym prowadzi konwersacje tak, by unikać tematów drażliwych, moralnie wattpliwych albo szczerych wyznań. Pojawiają się w tym przypadku często określenia takie jak „prymus” oraz „lizus”. W szkole ten typ nudziarza zawsze był przygotowany do zajęć, słuchał nauczycieli i ro- 
bił wszystko, by wkupić się w ich łaski. W dorosłym życiu chodzący ideał koncentruje się przede wszystkim na tym, by się nie wychylać: bardzo dużą wagę przywiązuje do tego, co powiedzą o nim inni, i za wszelką cenę realizuje modelowy wzór życia w ustalonej kolejności (najpierw nauka, potem praca, na końcu małżeństwo i rodzina). Uważa się, że taka osoba nigdy nie była spontaniczna: nie zrobiła niczego głupiego, szalonego, a przez to nigdy nie przeżyła prawdziwej przygody.

\section{Nudziarz z wyboru}

Ostatni wyróżniony typ to nudziarz z wyboru. Zaliczyć do niego można te osoby, które buntują się przeciwko konceptowi posiadania interesującego życia. Uważają je za trywialne, pozbawione głębszego znaczenia, skoncentrowane na pogoni za moda, rozrywką i ulotnymi przyjemnościami.

[...] np. taka Paris Hilton. Ludzie przecież ona ciagle robi to samo, impreza, jazda po pijanemu, aresztowanie, odwyk, impreza, jazda po pijanemu, odsiadka, odwyk, grzywna (zapomniałam o krótkich epizodach kinematograficznych tudzież pseudowokalnych). Czysta monotonnia :P, a niestety mało jest osób na świecie, którzy stwierdzą, że Paris to nudziara (Blueberry89 2015).

Z dystansem podchodzą do konieczności podejmowania społecznie cenionych aktywności albo realizowania poważanych norm społecznych. Wolą koncentrować się na tworzeniu „nowej jakości” w swoim życiu, alternatywnej wobec każdej formy, którą uznają za przymusowa.

Nasza kultura w swej zewnętrznej formie zdaje się być pełna radości, młodości i sukcesu, przez co nie widać, jak silnie w jej wnętrzu tli się znudzenie wszystkim, co łatwo dostępne, wymierne i przyjemne. Świat, który coraz mniej cieszy się z Bożych Narodzin, staje się coraz bardziej jednowymiarowy i nudny (Wieczorek 2015).

Część opisów pokrywa się z cechami/działaniami charakterystycznymi dla ruchu slow life: wybieranie uważnego, spokojnego stylu życia, bycie świadomym negatywnych konsekwencji konsumeryzmu, nacisk na rozwój wewnętrzny i szukanie odpowiedzi na pytanie o to, co jest naprawdę ważne dla jednostki. Opisy tworzone bezpośrednio przez ten typ osób pozbawio- 
ne sa, w przeciwieństwie do wcześniejszych typów, niepokoju o negatywna ocenę z zewnątrz. Nuda jest w tym przypadku postrzegana jako stan wart akceptacji i zagospodarowania w określony sposób. Dochodzi tu do przewartościowania: nuda przestaje być negatywna, staje się rodzajem odpoczynku, relaksu, tym, co pozwala zwolnić i rozwijać refleksyjność. W tym typie wiele wypowiedzi nosi znamiona stylu terapeutycznego: mówi się o akceptacji nudy, o pracy nad postrzeganiem siebie samego, o introspekcji.

[M]ówią, że ponoć inteligentni ludzie się nie nudzą... jakoś nie mogę się z tym zgodzić... ostatnio i mnie dopadła nuda... ale czasem dobrze sie ponudzić.... (aToja 2015).

To pewnie zabrzmi kretyńsko, ale podstawą do niebycia nudnym jest przekonanie samego siebie, że nie jest się nudnym. Potem już pójdzie (Kaktus 2015).

Brakuje tu też bezpośredniego połączenia cech takiej osoby z nudnym. Konstrukcja ta oparta jest na ciagłym zaprzeczaniu temu, że nieinteresujące życie jest nudne: opisy tego, co interesujące, pełne są ironii, sarkazmu oraz negatywnego wartościowania.

Idz do lozka z szefem, zacznij dosnosic na kolezanki, czesciej wychodz do galerii handlowych, zacznij jesc jakies sushi czy inne modne przysmaki, zobacz oferte okolicznych klubow i zaplanuj jakies egzotyczne wczasy. Wtedy z nudziary staniesz sie goraca bizneswoman (MHL 2015).

Ten typ nudziarza wybrał określony styl życia świadomie i podąża (równie świadomie) droga pozbawioną wszystkiego, co społecznie uznawane za interesujące, a co w rzeczywistości jest - jego zdaniem - nudne. Sam jednak podąża za pewnym trendem, dzięki czemu można nadać mu miano ,interesującego”, przez co tego rodzaju ucieczka zdaje się prowadzić w ślepą uliczkę:

Mnie jest poniekąd dobrze z tym, że jestem nudna. Ba, kiedyś myślałam, że w życiu chodzi tylko o to, żeby się wyróżnić. Ale ludzi nigdy nie zadowolisz, więc na przekór tym, którzy promuja oryginalność i nietypowość, ja obstaję przy klasycznej prostocie zachowania, obyczajów, estetyki. Po prostu nigdy nie będę taka jak 
niektórzy i uważam, że jestem z tego powodu po prostu różna od nich, a nie gorsza [...] (Islaja 2015).

Mniejszą liczebnie, ale nie mniej ciekawa grupę stanowią w tym typie nudziarze, którzy już nawet nie buntują się przeciwko ,interesującemu”. Ten podtyp afirmuje każdy przejaw codziennego, rutynowego życia. Najprostsze decyzje konsultowane sa z internetową społecznością, najbardziej codzienne, przyziemne wydarzenia sa tu dyskutowane. Tacy nudziarze nie określają sami siebie w odniesieniu do cech zewnętrznej rzeczywistości. Stwierdzają, że są nudni, dobrze się z tym czują i nie są bliżej zainteresowani, czy ktokolwiek zwróci na nich uwagę. Nie ma tu żadnej wyższej idei - jest tylko wspólnota połączona przekonaniem, że nuda to nieodłączny element życia i nie ma sensu na siłę przed nią uciekać ${ }^{6}$. Opisany tu typ nudziarza $\mathrm{z}$ wyboru pojawia się $\mathrm{w}$ analizowanym materiale raczej na marginesie rozważań o nudzie i tworzony jest w opozycji do głównych reprezentacji fenomenu „człowieka nudnego”. Nudziarz świadomy swej nudności nie jest aż tak negatywnie oceniany jak pozostałe wskazane tu typy. Jego opisy pojawiają się najczęściej jako autoprezentacje prawdopodobnie dlatego, że nie pasuje on do społeczno-kulturowego konceptu osoby nudnej o ugruntowanej pozycji w świadomości zbiorowej.

Lubię siedzieć w domu i czytać, surfować po Internecie, oglądać telewizję, chodzić do pracy. [...] Lubię się nudzić, nic nie robić, wylegiwać się. [...] Lubię swoje mieszkanie, mój kącik kochany, do którego wracam zawsze z tym samym entuzjazmem. Lubię wracać do swojego męża i do kota, a niedługo będę lubić patrzeć na swoje dziecko. Lubię spotkać się z przyjaciółmi, których mam naprawdę niewiele. Lubię przewidywalność dnia następnego i nie brakuje mi adrenaliny. Lubię swój zamknięty świat (blogging.skylark 2015).

Typ nudziarza z wyboru jest prawdopodobnie jedynym (wśród zaprezentowanych powyżej), który może dysponować potencjałem do zmieniania zastanego porządku społecznego. Analizowane wypowiedzi w tym typie charakteryzują się bezpośrednim umieszczeniem ,ja” w tekście i wskazują na dość wysoki poziom autorefleksyjności. Widoczna jest w nich też świadomość istniejących norm oraz podejmowanie prób kontestacji/przeobrażeń znaczeń łączonych z nudą i tym, co nudne. Na tej podstawie moż-

${ }^{6}$ Tego typu grupy funkcjonuja w przestrzeni wirtualnej, np. na portalu Facebook: „Boring”, „Boring Group for Original Bores”, „Dull Men Club”. 
na wnioskować, że nudziarzami z wyboru prawdopodobnie zostają osoby o wyższych kompetencjach społecznych (social skill, Filgstein 2001), które mają szansę i niezbędne umiejętności, by zmusić innych do wspólpracy i zmiany istniejących warunków. Nudziarze z wyboru mogą dokonać takiej zmiany, dlatego że wytwarzają własny subświat, który funkcjonuje obok innych rozwiązań i zwrotnie na nie oddziałuje.

\section{/// Współczesny człowiek nudny?}

Charakterystyka nudziarza tworzona jest za pośrednictwem dwóch podstawowych zabiegów. Pierwszy z nich to tautologia: człowiek nudny to taki człowiek, który jest... nudny i przynudza. To osoba pozbawiona właściwości, pozbawiona cech charakterystycznych tylko dla niej lub dla pewnej grupy społecznej. Kluczowa jest tutaj niemożność odnalezienia jakichkolwiek elementów różnicujących ją od innych osób lub do nich upodabniających. To ktoś, o kim nie można nawet powiedzieć, że jest przeciętny, ponieważ nie da się znaleźć słów na wszechogarniający brak właściwości nudziarza. Autorzy tekstów stosowali również utarte powiedzenia czy frazeologizmy, np. „nudni jak flaki z olejem”, „umrzeć z nudów”, „nudzić się jak mops”. Tautologie dotyczą też sytuacji, w której powielane jest stereotypowe przekonanie mówiące, że ,tylko nudni ludzie się nudzą". Chodzi tu też o rodzaj skłonności do popadania w znużenie, które następnie staje się podstawa do wnioskowania o charakterystykach jednostki. Drugi zabieg polega na odwoływaniu się do opozycji. W tym przypadku osoba nudna opisywana jest nie poprzez brak jakichkolwiek dystynktywnych cech, lecz poprzez brak cech człowieka ,interesującego” oraz poprzez niepodejmowanie aktywności, nieangażowanie się w praktyki społeczne uznawane za interesujące, np. chodzenie na imprezy, spotykanie się z przyjaciółmi, posiadanie hobby.

Podstawą wyszczególnienia typów nudziarzy są opisy charakterystycznych cech oraz zachowań przypisywanych osobom nudnym. W tym rozróżnieniu „osoba bez właściwości” przedstawiana jest jako ktoś, kto nie wyróżnia się spośród innych, nie nawiązuje relacji z innymi, jest obojętna lub permisywna, rzadko podejmuje aktywne działanie. Freak dysponuje zestawem silnie wyróżniających się cech i zachowań. Najczęściej uznaje się go za pasjonata, maniaka zaangażowanego wyłącznie w jedną, interesującą go aktywność. „Chodzący ideał” wyróżnia się na tle innych nudziarzy swoja perfekcyjnością i społeczna poprawnością. To człowiek, dla którego rutyna staje się podstawą wszelkiego działania. „Nudziarz z wyboru” to 
typ buntownika: nie zgadza się on na istniejącą definicję tego, co jest nudne $\mathrm{i}$ interesujące. Bycie nudnym uczynił elementem swojego życia, jednak - w przeciwieństwie do pozostałych trzech typów - jest tego świadomy i akceptuje ten stan.

Rozróżnienie to nie oznacza, że każdy nudziarz stanowi jednostkę odrębna, o pewnym i stabilnym zakresie cech lub zachowań. Każdy z typów może przejmować cechy innego (np. „nudziarz z wyboru” może być jednocześnie „chodzącym ideałem”) i budować nowa jakość. Jednocześnie istnieje pewien zespół cech wspólny dla wszystkich typów. Osoba nudna prezentowana jest jako niekompetentna w jakiejś dziedzinie. Najczęściej jest to nieumiejętność radzenia sobie na polu relacji społecznych połączona (w przypadku pierwszych trzech typów) z nieświadomością przyczyn tego stanu. Osoby nudne są dla otoczenia nieinteresujące, ponieważ nie dysponują kompetencją społeczną, która pozwala na nawiązywanie satysfakcjonujących relacji z innymi ludźmi. Nie potrafią też skutecznie rozwiązać swojego problemu, przez co najprawdopodobniej skazane są na samotność i towarzyskie wykluczenie.

\section{/// Nuda jako nadrzędne określenie nudziarza i tego, co nudne}

To, co „nudne”, charakteryzowane jest przez powtarzanie słów powiazanych z nudą w różnych formach. Zdaje się, że nuda najlepiej definiuje sama siebie. Nudziarz będzie jedynie rodzajem figury, odmiany nudy, którą można przypisać do człowieka7. Nuda staje się centralnym pojęciem (nodal point), wokół którego zorganizowane są inne określenia. To, co nudne, nudzenie (się), nudziarz, człowiek nudzący się wchodzą ze sobą w ścisłe relacje semantyczne i tworzą łańcuch znaczeń. Granice pomiędzy tymi określeniami ulegaja zatarciu. W dyskursie pod pojęciem nudy ostatecznie kryją się dwa znaczenia: ,nudny” oraz „nudzić (się)”. Nudny człowiek to taki, który nudzi się i zanudza innych: jest podmiotem odczuwającym nudę i dystrybuującym ją w relacjach społecznych. Nuda określana jest więc albo w kategoriach czynności (nudzić się, nudzić kogoś), albo w kategoriach naznaczających (nudny człowiek, nudna sytuacja). To uproszczenie wskazuje na dwa sposoby prezentacji nudy: jako etykietowania rzeczywistości oraz jako doświadczania jej uprzednio zdefiniowanej jako nudna. Dyskurs nudy budowany jest w opozycji do tego, co interesujące. Nuda wyklucza zainteresowanie i zaciekawienie. Nudziarz nie potrafi

\footnotetext{
${ }^{7}$ Słownik Języka Polskiego PWN podaje, że nuda to określenie opisujące nie tylko wewnętrzny stan, lecz także rzecz albo nieciekawą osobę.
} 
zainteresować innych, co oznacza, że zanudza, prowokuje nudę u innych, sam jest nudny. Nudzenie się traktowane jest z kolei jako możliwy objaw nieumiejętności odnalezienia tego, co interesujące, i w konsekwencji prowadzi do nadania podmiotowi nudzącemu się etykiety nudziarza. Sama nuda w tym kontekście lokuje się w relacjach między nudzeniem (się) a byciem zaciekawionym oraz między tym, co nudne, i tym, co interesujące. W badanym dyskursie momenty są okrajane z dodatkowych znaczeń, potencjalnych napięć i różnic, by dopasować je do jednoznacznego sposobu konceptualizowania nudy oraz wartościowania osób jej doświadczających/ dostarczających jej innym. W dyskursie dominują uproszczone sposoby patrzenia na nudę: podtrzymywana jest fikcja jedności, pewności czy stałości kreowanych znaczeń.

\section{/// Początki nowego dyskursu nudy?}

Jednocześnie jednak każde sformułowanie może doprowadzić do przeobrażenia z pozoru stabilnej sieci znaczeń, z której zbudowany jest dyskurs. Rozbicie utartych systemów znaczeń można obserwować przy próbach zerwania relacji nudzenie (się)/nudne - bycie zaciekawionym/interesujące. Rozerwanie tego połączenia zmusza do przemyślenia charakteru związków pomiędzy momentami oraz znaczeń, które są przypisywane do znaków. W tym miejscu można zaobserwować wykształcanie się nowego sposobu definiowania codziennych doświadczeń nudy oraz wartości, jakie przypisuje się osobom nudnym. Następuje wyraźne przesunięcie od negatywnego do neutralnego lub pozytywnego ujmowania nudy. Typ nudziarza z wyboru obrazuje opisywana zmianę, a może nawet początki wyłaniania się nowego dyskursu nudy.

Nowy dyskurs w symboliczny sposób przywraca nudzie elitarny, klasowy charakter, jednak już bez romantyczno-egzystencjalnych konotacji. Demokratyzacja nudy wyeliminowała doświadczenie nudy egzystencjalnej jako czegoś nobilitującego. Ukrytym efektem tego procesu było powstanie jednoznacznie negatywnych skojarzeń z nudą i jej wyraźne odróżnienie od tego, co interesujące. Nowoczesną nudę utożsamiono z brakiem szeroko pojętej satysfakcji. Obecnie takie podejście nie oddaje jednak całościowego kształtu nudy, ponieważ można zaobserwować procesy destabilizujące sieć utartych znaczeń. Zmiana znaczeń dokonywana jest przez aktorów o wyższych kompetencjach. Tworzy też takie podejście do nudy, z którym łatwiej utożsamiaja się osoby o wyższym poziomie refleksyjności i mniejsza skłonnością do biernego przyjmowania utartych kulturowych propozycji 
myślenia czy działania za własne albo jedynie słuszne. To z kolei może wskazywać na różnice klasowo-warstwowe pomiędzy nudziarzami reprezentującymi poszczególne typy. Nudziarz z wyboru zajmie w tym przypadku pozycję wyższa niż pozostałe typy. W konsekwencji podejście do nudy uwzględniające jej a mbiwalentność (w relacji do interesującego) może być częstsze w przypadku jednostek o wyższej pozycji.

Współczesność charakteryzowana jest przez płynność, przejściowość i niestabilność warunków, które wytwarza. Podobnie jest ze znaczeniami budowanymi wokół nudy. Nadanie etykiety „nudnego” ma jednoznacznie negatywne konotacje. Wyłaniające się w dyskursie nowe podejście do nudy przesuwa wartości kreowane wokół nudnego w stronę tego, co interesujące. Tym samym podważane jest klasyczne rozumienie „interesującego” i „nudnego”. W świecie, w którym nie możemy być niczego pewni, nie możemy również uznawać, że utarte kulturowe propozycje znaczeń są słuszne. Współczesna kultura preferuje dążenie do realizowania modelu człowieka, którego aktywność skoncentrowana jest wokół konsumpcji. Nadanie nudnemu znaczenia oscylującego wokół pozytywnej/neutralnej normalności można uznać za przejaw kontestacji tej wartości. To kontestacja zasady nakazującej bycie osobą pełną energii, optymistyczną, zawsze gotową do działania, spontaniczną, decyzyjna, wyróżniająca się z tłumu, otwarta, z polotem, często wychodząca $z$ domu, posiadającą modne przedmioty, oryginalne hobby i szeroki krag znajomych. Zmiana znaczenia nudy ma więc na celu wzbudzenie refleksji wobec wzorów zachowań czy stylów życia, które bierzemy za obiektywnie dane i pożądane. Tym samym bycie „interesującym” dla innych i siebie poprzez podejmowanie/niepodejmowanie określonych aktywności przestaje być niekwestionowalną wartością.

Wyłanianie się nowego dyskursu nudy samo w sobie powiększa obszary niepewności. To z kolei daje szansę na poszerzenie się możliwości (działania, mówienia, myślenia) dostępnych dla tożsamości (identities) ${ }^{8}$ poprzez wytworzenie punktów zwrotnych. Dynamika sieci społecznych widziana jest jako powiązana z dynamiką sieci znaczeń (White, Godart, Thiemann 2013: 137-138). Zwiększenie się obszarów niepewności daje w tym przypadku możliwość przeobrażania strategii stosowanych przez aktorów w relacjach społecznych. Nudziarz z wyboru posiada specyficzną kompetencję, która umożliwia mu wprowadzenie niepewności do utartego systemu znaczeń nudy i nudnego poprzez wskazanie, że oczekiwania

\footnotetext{
8 Tożsamości rozumiane są tutaj jako każdy rodzaj/typ aktywności/jednostki, zbiór ról, do których obserwator przypisuje znaczenie niezwiązane ze sferą biologiczną lub fizyczną (zob. White, Godart, Thiemann 2013: 137-154).
} 
wobec roli nudziarza nie odpowiadają wymogom współczesności. Tym samym pokazuje, jak istnienie roli osoby nudnej jest wymuszane przez zbiór specyficznych okoliczności zewnętrznych promujących ideę interesującego. W taki sposób otwiera się droga do społecznej akceptacji nudziarzy i budowania nowego skryptu relacji pomiędzy osobami nudnymi oraz między nimi a osobami interesującymi. Prawdopodobieństwo przetrwania nowego skryptu w dłuższym okresie czasu jest wciąż trudne do określenia. Analiza dyskursu dostarczyła informacji pozwalających jedynie na stwierdzenie istnienia zalążka zmian znaczeń. Nowy dyskurs nudy prawdopodobnie dopiero powstaje i nie jest jeszcze wystarczająco silny, by zdominować utarte propozycje. Podejmowanie prób odwrócenia znaczeń nudy/nudnego i interesującego może doprowadzić do reorganizacji społecznego życia jednostek uznanych (uznających się) za nudne, a w konsekwencji wyeliminować jednoznacznie negatywne oceny samego nudzenia się/samej nudy. Dopóki jednak nowy dyskurs nudy nie będzie wystarczająco silny, dopóty nudziarze zmuszeni będa do funkcjonowania na marginesach społecznej akceptacji.

\section{/// Współczesne doświadczenie nudy}

\section{Sytuacyjność/usytuowanie nudy}

Większość z przedstawionych powyżej opisów odwołuje się w dużym stopniu do sytuacyjności ocen zjawiska nudy.

[...] [J]a strasznie nie lubię jak ktoś nazywa drugiego człowieka nudnym. Dla każdego co innego będzie ,NUDNE'. Dla jednych oglądanie Star Wars, albo Harrego Pottera jest szczytem nudziarstwa, a inni się tym pasjonują. Co w tym złego? Możemy zmienić się nagle w wredne suki, albo udawać kogoś kim nie jesteśmy, żeby osoby X czy Y uznały nas za interesujące i „nienudne", ale po co, dla nich? [...] Ja właśnie staram się nie uważać siebie za nudziarę. Jak ktoś mnie za taką uważa to jego problem? (Blueberry89 2015).

To, co nudne jest silnie uzależnione od czasu trwania, obecności pewnego zachowania i kulturowej wizji interesującego. Nuda postrzegana często jako potrzeba robienia czegoś, (niezaspokojona) potrzeba umysłowej aktywności (por. Goodstein 2005: 398-420, Fenichel 1953) wydaje się też 
fenomenem społecznym. Trudno zaakceptować założenie mówiące o pewnej wewnętrznej naturze, która ma sprawiać, że odczuwamy nudę w określony sposób. Nuda jest zależna od kontekstu kulturowego, społecznego: dla każdej grupy społecznej nudne będzie coś innego, w każdej kulturze nudne będzie definiowane inaczej. Na nudę należy patrzeć jak na zjawisko sytuacyjne: jej odczuwanie zmienia się pod wpływem konkretnych, codziennych mikrodoświadczeń. Ta sama sytuacja może generować uczucie nudy, które będzie nie do zniesienia lub względnie niezauważalne. Wszystko zależy od społecznych znaczeń przypisywanych pojedynczym zdarzeniom w danych społeczno-kulturowych kontekstach. Nie oznacza to jednak, że nuda to pojęcie puste, wypełniane przez zbiór przypadkowo nadarzających się okoliczności. Nuda jest usytuowana w określonych kontekstach i definiowana za pośrednictwem swoich przeciwieństw.

Zebrany materiał pozwala na wysunięcie wniosku, że odczuwanie nudy i definiowanie tego, co lub kto jest nudne/nudny, wynika z niemożności wypełnienia oczekiwań społecznych. Te oczekiwania dotyczą głównie konceptu ,interesującego”. Nuda konstruowana jest przede wszystkim w odniesieniu do tego, co stanowi jej zaprzeczenie (do „interesującego”). Brak elementów, które czynią życie interesującym, staje się początkiem tworzenia nudy jako problemu psychologicznego i estetycznego (Dalle Pezze, Salzani 2009: 23). Problem ten może zostać rozwiązany na kilka sposobów, przy czym za najskuteczniejsze lekarstwo uważa się współcześnie wypełnienie swojego życia i codziennego doświadczenia tym, co interesujące (tamże). Należy poszukiwać rozrywki, odmiany, uciekać od monotonii, wymyślać dla siebie nowe zajęcia oraz rozwijać wyobraźnię (McDonald 2009: 60). Chodzi tu przede wszystkim o bodźce, które podtrzymuja wewnętrzne napięcie i wypełniają czas pustki, czas pozbawiony głębszego sensu i znaczenia (Dalle Pezze, Salzani 2009: 13).

„Nudne” jest bardzo silnie napiętnowane i pociąga za sobą negatywne konotacje. Dotyczy to zarówno praktyk definiowanych jako nudne w danym kontekście, jak i osób podejmujących te praktyki. Nazwanie kogoś „nudziarzem” staje się formą krytyki, wyrazem dezaprobaty, a nawet obelgi. Człowiek nudny to prawdopodobnie najmniej pożądana kategoria w towarzystwie. Jest on sprowadzony do kogoś obcego, kogo się wyklucza, nie zaprasza, z kim nie spędza się czasu, kogo się unika. Na tej podstawie można przypuszczać, że samo obcowanie z „nudnym” obarczone jest strachem przed odrzuceniem przez innych. 


\section{Relacyjność nudy}

W tym momencie konieczne staje się zwrócenie uwagi na relacyjność tego zjawiska. Nuda odczuwana jest wobec czegoś/kogoś lub w związku z czymś/kimś. „Nudne” zależy więc od interpretacji doświadczenia: uznanie czegoś lub kogoś za nudne nie jest tym samym, co określenie obiektywnie istniejących cech (to nie oznacza jednocześnie, że nie istnieją pewne wspólne desygnaty „nudnego”). Nuda funkcjonuje w relacjach pomiędzy jednostkami społecznymi. Nie można być nudziarzem, gdy nie wchodzi się w interakcje z innymi, gdy nie próbuje się innych naśladować lub gdy nie ma się punktu odniesienia. We współczesnym świecie, jak wynika z analizowanych materiałów, za ten punkt odniesienia można przyjąć „bycie interesującym". Taka sytuacja powoduje inne problemy.

Podstawa jakościowo znaczącego doświadczenia staje się to, co podniecające, fascynujące, pasjonujące (exciting), oraz to, co wywołuje dreszcz emocji (thrilling). Jednostki rozbudzają w sobie różnorodne pragnienia, które ostatecznie okazują się niemożliwe do pełnego doświadczenia czy odczucia. W efekcie pogłębiają wrażenie niespełnienia, łączonego z faktem, że stymulacja ma źródło zewnętrzne (por. Dalle Pezze, Salzani 2009: 13). W otaczającym świecie jednostki poszukuja specyficznego rodzaju znaczenia, które ma swe korzenie w romantycznej wizji rzeczywistości społecznej. Przedstawiciele romantyzmu przerzucili winę za odczuwanie znudzenia z jednostki na opresyjny porządek społeczny (Klapp 1986: 27). Ludzie, jak podkreśla Svendsen (2005: 30), stają się uzależnieni od poszukiwania i posiadania sensu, znaczenia w życiu. Nie chca, by ich doświadczenie było wypełnione nuda, pustką albo tym, do czego powszechnie przypisuje się etykietę bezwartościowego. Dlatego też, jak zaznacza Orrin Klapp (1986: 20), dużą popularnością cieszą się ,instytucje placebo”: rozrywka, hazard, sport, używki, środki masowego przekazu. Instytucje te, zdaniem Klappa, łagodza albo maskuja problem nudy po to, by ludzie nie zdawali sobie sprawy z własnych, wewnętrznych potrzeb. Substytuty zastępujące sens (social placebos) tworzą sztuczne odpowiedniki znaczenia (ersatz-meaning) i iluzję sensu (tamże, Svendsen 2005: 26, 79). W konsekwencji ucieczka przed nuda prowadzi do wypełniania czasu rozrywkami, które de facto także można uznać za nudne i których jedynym celem jest zapełnianie pustego czasu (por. Svendsen 2005: 26-29). W tym kontekście można powiedzieć, że nuda pojawia się wtedy, gdy codzienne życie traci społecznie cenione cechy lub znaczenie albo gdy „potrzeba sensu” jest niespełniona, co Svendsen określił jako meaning withdrawal (tamże: 30). Kryzys znaczenia sprawia, że 
współczesny podmiot upodabnia się do „pełnoetatowego turysty” (full-time tourist) (tamże: 79). Głównym celem tego ponowoczesnego wzoru osobowego opisanego przez Baumana (1994: 30-33) jest zdobywanie doświadczeń: koniecznie nowych, niecodziennych, związanych z tym, co inne, ale też niepozbawionych przewidywalności. Turysta kolekcjonuje wrażenia, by następnie móc się nimi pochwalić. Można założyć, że kolekcjonowanie wrażeń staje się narzędziem ucieczki przed nadaniem społecznej etykiety człowieka nudnego, nudziarza.

Definiowanie „nudnego” w opozycji do „interesującego” prowadzi wprost do ambiwalencji. Oba te konstrukty są niejednoznaczne. Nuda stała się „uniwersalnym (all-purpose) wskaźnikiem niezadowolenia” (Spacks 1995: 249). Odnosi się ona do wyizolowanych jednostek, które żyją w sfragmentaryzowanym świecie, zsekularyzowanym i pozbawionym trwałych, stabilnych tradycji, a także do jednostek niemogących znaleźć schronienia we wspólnotach oraz sensu w podejmowanej pracy czy zadowolenia w bezczynności (tamże: 219, 249-251). Taka wizja rzeczywistości społecznej prowadzi do wniosku, że celem staje się pogoń za tym, co interesujące, oraz ucieczka przed nuda (McDonald 2009: 63), którą się znosi lub z powodu której się cierpi (zob. Spacks 1995). Jednostki podejmują cały szereg działań, daremnych prób, by wykluczyć nudę ze swojego doświadczenia, ale nie moga tego dokonać, ponieważ przenika ona całe ludzkie życie w sposób nieskończony (Tardieu 1903, za: Goodstein 2005: 163-168). Wielość możliwych wyborów może przytłaczać i prowadzić do braku zadowolenia. Wynika to z faktu, że możliwość wyboru pociaga też za sobą możliwość odrzucenia: w ten sposób wszystko, co nas otacza, zostaje pozbawione wartości. Różnorodność wyborów sprawia, że znaczą one coraz mniej (Svendsen 2005: 143-154). Tym samym granica między ,interesującym” a „nudnym” się zaciera. Jednocześnie nowoczesny podmiot wciąż spotyka się z wymogiem, by prowadzić interesujące życie i by poszukiwać takich aktywności, obiektów, doświadczeń, które są społecznie uznawane za „interesujące” oraz „znaczące”, ale już niekoniecznie za „wartościowe” (por. tamże: 27-28).

Nudziarze z wyboru dokonuja prób zmiany znaczeń i podejść, jednak nie można tutaj mówić o pełnej transformacji, lecz jedynie o jej zalążku. Pejoratywne skojarzenia dotyczące nudy zachowują swoją silną pozycję. Nuda pojawia się w momencie, gdy jednostki nie dysponują kompetencja (Fligstein 2001) do budowania relacji na polu tego, co uznawane za interesujące. Ostatni typ osób nudnych, korzystając z warunków niepewności i płynności, próbuje jednak zawłaszczyć to pole i przetransferować część 
znaczeń „nudnego” w stronę ,interesującego”. W dyskusjach na temat nudziarzy pojawiają się nieustannie ironiczne odniesienia do konceptu ,interesującego". Uparte dążenie do bycia człowiekiem ciekawym, intrygującym, interesującym postrzegane jest jako płytka, pozbawiona samoświadomości, sztuczna kreacja siebie. Za bardziej naturalne i społecznie pożądane uznaje się więc bycie „refleksyjnie” nudnym (ale tylko w pewnych granicach!). Świadomość negatywnych konsekwencji ślepego podążania za medialnymi przedstawieniami „interesującego” postrzegana jest jako dojrzałość. Każdy jest w jakimś sensie nudny, ale tylko nieliczni potrafia to sobie uzmysłowić i zaakceptować. W zebranych tekstach akceptacja nudy ma być lekarstwem na poczucie winy oraz wstydu, jakie wywołuje samo wrażenie, że posiada się cechy typowe dla nudziarza. Nie zmienia to jednak faktu, że nie wypada być nudziarzem w zbyt dużym stopniu. $Z$ jednej strony, nie można być interesującym na siłę, poprzez imitowanie obowiązujących mód (to też uznaje się za nudne). Z drugiej - zbyt nijakim, zbyt monotematycznym, zbyt ugrzecznionym. Problem takiego skonstruowania wizji nudy w dyskursie tkwi w niekonsekwencji, niejasności jej sformułowania. Współcześnie każe się nam szukać złotego środka, ale nie ustala się stabilnych granic na początku oraz na końcu skali. Nie wiadomo do końca, co posiada wartość, co jest znaczące albo interesujące: wspólnoty nie stanowia już punktu odniesienia dla jednostek, znaczenie znajduje się w kryzysie, podobnie jak tożsamość. Taka sytuacja potwierdza założenie o płynności i niepewności współczesności. To z kolei uwidacznia, że nuda jest powiązana z konkretnym czasem oraz miejscem: jest zjawiskiem typowym dla nowoczesności (Dalle Pezze, Salzani 2009, Goodstein 2005) i jak wiele innych zjawisk mających społeczną naturę, przejmuje cechy typowe dla nowoczesnego ładu.

\section{Ambiwalentność nudy}

Napiętnowanie bycia nudnym w ciekawy sposób odnosi się do jego jednoczesnego afirmowania. Wydaje się, że to, co nudne, może istnieć jedynie o tyle, o ile nie dysponuje świadomościa posiadania tej cechy. Kiedy bycie nudziarzem staje się wyborem, pozbawiane jest aż tak silnych negatywnych konotacji. W tym miejscu kluczowa staje się kategoria „świadomego wyboru". Tkwi w tym pewien paradoks: $z$ jednej strony bycie nudnym jest społecznie niepożądane, z drugiej - ze względu na to, że narzuca się nam obowiązek bycia interesującymi - bycie nudnym zaczyna stawać się formą buntu lub oznaka refleksyjności. Refleksyjność, świadomość sa z kolei postrzegane jako pozytywne, co prawdopodobnie zmniejsza po- 
ziom obarczenia „nudnego” negatywnymi znaczeniami. Dlatego można przypuszczać, że typ opisany tu jako nudziarz z wyboru cieszy się jakimś rodzajem poważania, ponieważ umiejętność podejmowania decyzji dotyczących sposobu budowania swojego stylu życia należy współcześnie do zalet. Tym samym typ ten symbolicznie pozbywa się braku właściwości i zamienia ów brak w wartość. W świecie, w którym niemal wszystko można kupić, w którym występuje raczej nadmiar wrażeń niż ich niedobór, celowe uciekanie od przesytu, wielości, stymulacji, konsumpcji na pokaz wydaje się niezwykle cenne i godne szacunku. Typ nudziarza z wyboru wykazuje pewne podobieństwa do koncepcji „klasy próżniaczej” Veblena (2008): „bycie nudnym” realizowane jest na pokaz, wybór „,nudnego” staje się kryterium standardu życia, zaś współzawodnictwo majątkowe zamienia się we współzawodnictwo o ,jakość” świadomego doświadczania rzeczywistości. W ten sposób ujawniają się związki nudy z różnicami klasowo-warstwowymi. Nudziarze z wyboru będą w tym kontekście reprezentować podejście do nudy charakterystyczne dla osób o wyższych kompetencjach/ wyższej pozycji. Postrzeganie nudy jako zjawiska, na które jest się skazanym, łączone będzie z niższą pozycją, w przeciwieństwie do kreatywnego i kontestującego podejścia do znaczeń „nudnego” czy „interesującego”.

Demokratyzacja nudy jest w analizowanym dyskursie silnie obecna. Stwierdzenia, że nudę może odczuwać każdy, pojawiają się w formie wtrąceń, stanowią zasób wiedzy podzielanej przez wszystkich autorów. Założenie to wydaje się mieć jednak pewne ukryte konsekwencje. Skoro nuda może dopaść każdego, to każdy może stać się nudny i w efekcie zostać negatywnie oceniony. Tym samym odczuwanie nudy jest często utożsamiane $z$ byciem nudnym. Taka presupozycja, nawet jeśli nie jest obiektywnie prawdziwa, pozwala na wyrażenie opinii o nudzie. Na tej podstawie można wnioskować, że upowszechnienie doświadczenia nudy powinno być rozpatrywane w powiązaniu z jego napiętnowaniem. Nie jest to, rzecz jasna, jedyny czynnik. Dopóki nuda była przywilejem nielicznych, elit i uznawano ja za coś niedostępnego pozostałym członkom społeczeństwa, dopóty mogła nosić znamiona wyjątkowości. Współcześnie straciła tę ekskluzywność. Można przypuszczać, że obecność w dyskursie typu nudziarza z wyboru jest wyrazem próby przywrócenia dawnych znaczeń nudy, oczywiście w zrekonstruowanej, bardziej odpowiadającej współczesności formie. Nie chodzi tu o kultywowanie staroświeckich cech jak u Veblena (tamże: 178204), ale o nawiązanie do przyspieszonego rozwoju świata na skutek procesów technologicznych, globalizacyjnych i rynkowych. W dyskursie obecna jest myśl, że w przeszłości ludzie żyli wolniej, nie posiadali aż tak wielu 
rozrywek, częściej wykonywali ciężką, monotonna pracę i nie potrzebowali aż tak wielu wrażeń. Można powiedzieć, że nudzili się mniej, chociaż (pozornie) mieli ku temu więcej powodów niż współcześni ${ }^{9}$ W tym sensie akceptacja nudnego ponownie zostaje przedstawiona jako wyraz uwagi i podwyższonego poziomu samoświadomości. Ten typ doświadczenia nie należy jednak do dominujących: przekonanie o tym, że bycie nudnym jest czymś nieodpowiednim, zdecydowanie przeważa w zebranym materiale.

\section{/// Podsumowanie}

Znaczenia „nudnego” pojawiające się w analizowanych tekstach w dużej mierze odpowiadają ustaleniom badaczy tego zjawiska. Nudne powiązane jest $\mathrm{z}$ brakiem bodźców, które w danym momencie mogą zainteresować jednostkę (understimulation), ale też z ich nadmiarem (overstimulation). Nudne jest również to, co pozostaje „poza”, co nie jest włączane do danego systemu interakcji: nudny człowiek jest skazany na odrzucenie, a niekiedy nawet na samotność. Nudne jest wszystko to, co niesie ze soba powtarzalność, monotonię i co daje się przewidzieć, chodzi tu szczególnie o brak nowości wywołującej podekscytowanie. Kategoria „nudnego” należy do zjawisk posiadających społeczną, relacyjną naturę. Nic nie jest nudne obiektywnie, lecz zawsze w odniesieniu do czegoś/kogoś interesującego. „Nudne” uzależnione jest także od kontekstu kulturowego oraz sytuacyjnego. Jednocześnie istnieją wspólne, podzielane znaczenia „nudnego”, budowane na bardziej ogólnym poziomie. Bycie nudnym stało się współcześnie rodzajem piętna, wywołuje wiele negatywnych konotacji. Jednocześnie jednak pojawiają się tendencje przeciwne: „nudne”, jeśli świadomie wybrane, traci stygmatyzujące znaczenie i staje się oznaką refleksyjności. Podobnie dzieje się wtedy, gdy nuda dopada kogoś rzadko: zakłada się wówczas, że może być przyczyną wzrostu kreatywności. Nuda jest zjawiskiem typowym dla nowoczesności, wpisuje się w cechy tego porządku i odzwierciedla niepokoje współczesnego pomiotu.

Bibliografia:

/// Bauman Z. 1994. Dwa sækice o moralności ponowoczesnej, Instytut Kultury.

\footnotetext{
${ }^{9}$ Wielu autorów podkreśla, że powiększanie się obszarów nudy we współczesności ma swoją główną przyczynę w rozwoju nowoczesnych technologii.
} 
/// Brissett D., Snow R. 1993. Boredom: Where the Future isn't, „Symbolic Interaction", nr 16(3), s. 237-256.

/// Dalle Pezze B., Salzani C. 2009. Introduction. The Delicate Monster: Modernity and Boredom, [w:] Essays on Boredom and Modernity, red. B. Dalle Pezze, C. Salzani, Rodopi, s. 5-34.

/// Fenichel O. 1953. The Psychology of Boredom, [w:] The Collected Papers of Otto Fenichel, red. O. Fenichel, H. Fenichel, D. Rapaport, W. W. Norton \& Co, s. 292-302.

/// Filgstein N. 2001. Social Skill and the Theory of Fields, „Sociological Theory", nr 19(2), s. 105-125.

/// Goodstein E. 2005. Experience without Qualities: Boredom and Modernity, Stanford University Press.

/// Kuhn R. 1976. The Demon of Noontide: Ennui in Western Literature, Princeton University Press.

/// Jørgensen M., Phillips L. 2002. Discourse Analysis as Theory and Method, Sage.

/// Laclau E. 2002. Dyskurs, tłum. C. Cieśliński, [w:] Przewodnik po wspótczesnej filozofii politycznej, red. R. Goodin, F. Pettit, C. Cieśliński, M. Poręba, Książka i Wiedza, s. 555-562.

/// McDonald W. 2009. Kierkegaard's Demonic Boredom, [w:] Essays on Boredom and Modernity, red. B. Dalle Pezze, C. Salzani, Rodopi, s. 60-84.

/// Spacks P. 1995. Boredom: the Literary History of a State of Mind, University of Chicago Press.

/// Svendsen L. 2005. A Philosophy of Boredom, tłum. J. Irons, Reaktion Books.

/// Tardieu É. 1903. L’Ennui. Étude psychologique, Félix Alcan.

/// Toohey P. 2012. Historia nudy, tłum. K. Ciarcińska, Bellona.

/// Veblen T. 2008. Teoria klasy próżniaczej, tłum. J. Frentzel-Zagórska, Wydawnictwo Muza.

/// White H., Godart F., Thiemann M. 2013. Turning Points and the Space of Possibles: A Relational Perspective on the Different Forms of Uncertainty, [w:] Apply- 
ing Relational Sociology: Relations, Networks, and Society, red. F. Dépelteau, C. Powell, Palgrave Macmillan, s. 137-154.

/// Wodak R., Krzyżanowski M., red. 2011. Jakościowa analiz̧a dyskursu w naukach społecznych, tłum. D. Przepiórkowska, Oficyna Wydawnicza Lośgraf.

/// Zdrenka M. 2012. O gnuśności. Studium lenistwa i jego kontekstów, Wydawnictwo Naukowe Uniwersytetu Mikołaja Kopernika.

Źródła internetowe:

/// Anemonne. 2015. Cqłowiek nudny, http://www.netkobiety.pl/t38306. html; dostęp: 07.2015.

/// a'Toja. 2015. http://qz.pl/glowna.php?dzial=temat\&artykul=95; dostęp: 07.2015.

/// blogging.skylark. 2015. Jestem nudna, http://bloggingskylark.blogspot. com/2009/08/jestem-nudna.html; dostęp: 07.2015.

/// Blueberry89. 2015. http://www.phobiasocialis.fora.pl/login.php?redirect=/radzenie-sobie-i-powodzenie-w-zyciu,12/co-robic-aby-nie-byc-nudnym,5818.html; dostęp: 07.2015.

/// Crucible. 2015. Porzqdny facet = nudny facet?, https://goo.gl/Ite9O3; dostęp: 07. 2015.

/// dziku_SKA 2015. Człowiek nudny, http://www.netkobiety.pl/t38306. html; dostęp: 07.2015.

/// Gość. 2015. Czy jeśli jest się nudnym i ma sie nudne życie to zansze tak bedzie?, http://pytamy.pl/kat,19,title,czy-jesli-jest-sie-nudnym-i-ma-sie-nudnezycie-to-zawsze-tak-bedzie,pytanie.html?smclgnzlticaid=6193d9; dostęp: 06.2014 .

/// Honorata. 2015. Romantycznie? Z tym nudziarzem?, za: http://goo.gl/LUa2gy, dostęp: 07.2015 .

/// Islaja. 2015. http://www.phobiasocialis.fora.pl/login.php?redirect=/ radzenie-sobie-i-powodzenie-w-zyciu,12/co-robic-aby-nie-byc-nudnym,5818.html; dostęp: 07.2015. 
/// Izabela B. 2015. Nudna driewcryna, http://www.goldenline.pl/grupy/Organizacje_i_stowarzyszenia/klub-dyrektorow-kreatywnych/od-czego-tozalezy-ze-jedni-ludzie-sa-interesujacy-a-inni-nudni,1125930; dostęp: 07.2015. /// jasnoniebieska. 2015. Oręrie dla młodych driewcryn, http://jasnoniebieska.blog.onet.pl/2013/05/09/oredzie-dla-mlodych-dziewczyn/; dostęp: 07.2015.

/// kaisa_malene. 2015. Porzqdny facet = nudny facet?, http://www.netkobiety. pl/t28781.html; dostęp: 2015.

/// Kaktus. 2015. http://www.phobiasocialis.fora.pl/login.php?redirect=/radzenie-sobie-i-powodzenie-w-zyciu,12/co-robic-aby-nie-byc-nudnym,5818.html; dostęp: 07.2015.

/// mata hari. 2015. Nudny facet?, http://www.netkobiety.pl/t33992.html; dostęp: 05.2017.

/// Mijanou. 2015. Nudna driewczyna, http://wizaz.pl/forum/showthread. php?t=721877; dostęp: 07.2015.

/// MHL. 2015. http://www.phobiasocialis.fora.pl/login.php?redirect=/ radzenie-sobie-i-powodzenie-w-zyciu,12/co-robic-aby-nie-byc-nudnym,5818.html; dostęp: 07.2015.

/// Olgida. 2015. Czy jestés nudny? Sprawdǽ!, za: http://goo.gl/gerVmB, dostęp: 07.2015.

/// RuMcajs.!. 2015. Czy ja jestem nudziarzem?, https://goo.gl/chmswX; dostęp: 07.2015.

/// szafiareczka2014. 2015. Nudny facet:(, http://forum.szafa.pl/9/7685706/ nudny-facet.html; dostęp: 07.2015.

/// Sasza. 2017. Cz̨owiek nudny, http://www.netkobiety.pl/t38306.html; dostęp: 05.2017.

/// Wieczorek B. 2015. Nuda to choroba duszy, www.deon.pl/inteligentne-zycie/psychologia-na-co-dzien/art,86,nuda-to-choroba-duszy.html; dostęp: 07.2015.

/// Wielokropek. 2015. Cqłowiek nudny, http://www.netkobiety.pl/t38306. html; dostęp: 05.2017. 


\section{/// Abstrakt}

Poniższy artykuł stanowi próbę rekonstrukcji znaczeń przypisywanych pojęciu nudy oraz kategorii człowieka nudnego. Pierwsza część tekstu koncentruje się na krótkim omówieniu najważniejszych ustaleń pojawiających się w literaturze przedmiotu z naciskiem na elitaryzację i demokratyzację nudy. Druga część stanowi omówienie głównych wniosków z badań własnych: cech i zachowań współczesnego nudziarza oraz przypisywanych im wartości. Trzecia część tekstu przedstawia sytuacyjność, relacyjność oraz ambiwalentność zjawiska nudy przez pryzmat przeprowadzonych analiz.

Słowa kluczowe:

nuda, nudziarz, nudny człowiek, elitaryzacja nudy, demokratyzacja nudy, sytuacyjność nudy, relacyjność nudy, ambiwalentność nudy

\section{/// Abstract}

This paper is an endeavor to reconstruct the meanings ascribed to boredom and the category of "boring person." The first part of the paper is a short summary of the most important findings appearing in the literature on the subject, with a stress on the elitism and democratization of boredom. The second part concerns the main findings of the author's own research: the traits and behaviors of contemporary bores and the values attached to them. In the third part, the situational aspects, relativity, and ambivalence of the phenomenon of boredom are discussed.

Keywords:

boredom, bores, boring person, elitarisation of boredom, democratisation of boredom, boredom as situated phenomena, relational boredom, ambivalence of boredom 